\title{
Dolegliwości bólowe wynikające z zaburzeń stawów krzyżowo-biodrowych oraz więzadeł dziatających bezpośrednio i pośrednio na stawy
}

\section{Ailments resulting from deviations in sacroiliac joints and their ligaments}

\author{
Wioletta Jagucka-Mętel ${ }^{1}$, Anna Machoy-Mokrzyńska ${ }^{1}$, Adam Nowicki $^{2}$, Ewa Sobolewska ${ }^{\circledR}$ \\ ${ }^{1}$ Pomorski Uniwersytet Medyczny w Szczecinie, Katedra i Zakład Farmakologii Doświadczalnej i Klinicznej, al. Powstańców Wlkp. $72,70-111$ Szczecin \\ 2 Przychodnia Stomatologiczna „Mardent" w Wolinie, ul. Prosta 1, 72-510 Wolin \\ ${ }^{3}$ Pomorski Uniwersytet Medyczny w Szczecinie, Katedra i Zakład Protetyki Stomatologicznej, al. Powstańców Wlkp. 72, 70-111 Szczecin \\ $\triangle$ gerostom@pum.edu.pl
}

\begin{abstract}
Sacroiliac pathologies cause pain in the lumbosacral region, gluteal muscles and lower limbs. Pain radiating from a blocked
\end{abstract}

\section{ABSTRAKT}

Patologie stawu krzyżowo-biodrowego oraz więzadeł pośrednich i bezpośrednich tego stawu są jedną z przyczyn dolegliwości w obrębie odcinka lędźwiowo-krzyżowego kręgosłupa pośladka i kończyn dolnych. Dolegliwości bólowe pochodzące sacrolumbar joint often mimic radiculopathy. Adequate functional testing can help to obtain a proper diagnosis.

Keywords: sacroiliac joint; dysfunction; tests.

\section{WSTĘP}

Parzyste stawy krzyżowo-biodrowe, które wchodzą w skład obręczy biodrowej, utworzone są z powierzchni uchowatych znajdujących się na kości krzyżowej i talerzach biodrowych (ryc. 1). Staw krzyżowo-biodrowy zaliczany jest do stawów maziówkowych. Powierzchnia stawowa kości krzyżowej jest wyściełana chrząstką szklistą, a kości biodrowej chrząstką włóknistą, bardziej niebieską, mętną i prążkowaną. Różnią się one również grubością - chrząstka szklista kości krzyżowej jest 3-5 razy grubsza od chrząstki włóknistej kości biodrowej.

Torebka stawowa (capsula articularis) składa się z dwóch warstw - zewnętrznej włóknistej oraz wewnętrznej maziowej. Przednia część torebki jest wyraźnie oddzielona od więzadła
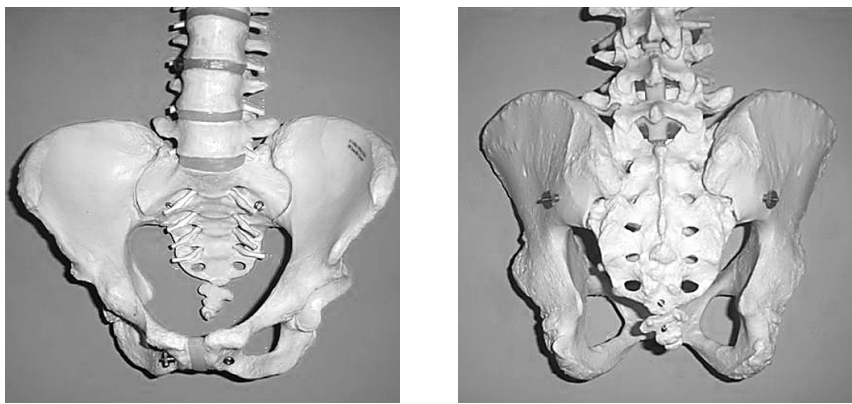

RYCINA 1. Staw krzyżowo-biodrowy z zablokowania stawu krzyżowo-biodrowego mylone są często $\mathrm{z}$ objawami pochodzenia korzeniowego. Zastosowanie odpowiednich testów funkcjonalnych umożliwia postawienie właściwej diagnozy.

Słowa kluczowe: staw krzyżowo-biodrowy; zablokowanie; testy.

krzyżowo-biodrowego brzusznego (ligamenta sacroiliaca ventralia), a tylna jej część jest wymieszana z włóknami głębokiego więzadła międzykostnego. Nieco poniżej torebka łączy się z okostną pokrywającą kość krzyżową i biodrową. Torebka stawowa wzmacniana jest przez otaczające struktury, powięzi i więzadła.

Zakres ruchu w stawie krzyżowo-biodrowym jest minimalny i wynosi ok. $4^{\circ}$ rotacji i 1,6 $\mathrm{mm}$ translacji. U mężczyzn zakresy ruchu są średnio o 30-40\% mniejsze [1]. Niewielka ruchomość tych stawów jest wynikiem ruchów w obrębie tułowia i kończyn dolnych. Odbywają się one w trzech płaszczyznach i są połączeniem ruchu zgięcia i wyprostu, górno-dolnego ślizgu oraz przednio-tylnej translacji. Połączenie ruchów rotacji i translacji kości krzyżowej daje w efekcie nutację i kontrnutację [2, 3]. Te niewielkie, lecz bardzo ważne ruchy mają wpływ na wyrównanie asymetrii i amortyzację przenoszonych obciążeń.

Z punktu widzenia biomechaniki staw ten spełnia funkcję stabilizacyjną w trakcie przenoszenia obciążeń oraz funkcję lokomocyjną. W trakcie stabilizacji konieczna jest integracja trzech układów (systemów): biernego (kostno-stawowo-więzadłowego), czynnego (mięśniowo-powięziowego) oraz nerwowego, który kontroluje dwa pierwsze. Wzajemne oddziaływanie wymienionych systemów pozwala na wykonywanie ruchów wg właściwych wzorców ruchowych, zaś zaburzenie któregokolwiek z nich doprowadza do przeciążeń kompensacyjnych i wtórnych uszkodzeń $[4,5]$. Levangine uważa, iż asymetria 
w budowie miednicy oraz odcinka lędźwiowego kręgosłupa przyczynia się do mechanicznych zaburzeń struktur tkanki miękkiej (przyczepiających się w obrębie tego stawu oraz elementów należących do niego) [6].

\section{ZAGADNIENIE GŁÓWNE}

Dolegliwości bólowe pochodzące ze stawów krzyżowo-biodrowych związane są z zaburzeniami w obrębie samego stawu (zablokowanie i nadruchomość), a także w obrębie tkanki miękkiej, która go otacza (przede wszystkim więzadła pośrednio i bezpośrednio działające na ten staw). Dochodzi do tego na skutek przeciążeń i sumujących się mikrourazów [7, 8].

Najczęstszym zaburzeniem w obrębie samego stawu jest zablokowanie czynnościowe, które polega na przemieszczeniu się kości krzyżowej względem kości biodrowej. Dochodzi wówczas do zaryglowania na wyniosłościach stawu, co uniemożliwia wykonanie ruchu powrotnego. Dużo rzadziej spotyka się z nadruchomość (hipermobilność), której przyczyną jest nadmierne rozciągnięcie więzadeł spowodowane mikrourazami, dysbalansem mięśniowym, a w szczególności zmiany hormonalne. Rozluźnienie więzadeł i brak stabilizacji w trakcie ruchów zginania i skręcania doprowadza do rozejścia się kości biodrowej względem kości krzyżowej. Poszerza się szpara stawowa, powodując niestabilność stawu krzyżowo-biodrowego. W tej sytuacji więzadła tego stawu są bardziej obciążone. Zmusza to układ mięśniowo-powięziowy do generowania większego napięcia $[8,9]$.

Więzadła pośrednio i bezpośrednio działające na staw krzyżowo-biodrowy mogą doprowadzić do zablokowania tego stawu, a pokrywająca się topografia bólu może mieć różne pochodzenie. Rzadko kiedy w gabinecie lekarskim badane są wyżej wymienione więzadła. Najczęściej lekarze sugerują się widocznymi zmianami w badaniach obrazowych, dlatego też ważnym wydaje się porównanie bólu pochodzącego z zaburzonych więzadeł i innych patologii $[7,8,10]$.

Dla przykładu, ból z więzadeł krzyżowo-biodrowych najczęściej umiejscowiony jest w okolicy kości krzyżowej i samego stawu krzyżowo-biodrowego. Niekiedy ból ten promieniuje do pachwiny, czasami do jąder u mężczyzn, a także do kończyny dolnej (tylno-zewnętrzna powierzchnia uda i podudzia). Topografia tego promieniowania przypomina ból przy ucisku na korzeń L5 i S1, dlatego jego przyczyna często mylona jest $\mathrm{z}$ dyskopatią lub z rwą kulszową (ischialgią) [9, 11].

Innym przykładem trudności diagnostycznych jest patologia więzadła krzyżowo-guzowego. Podobna topografia bólu występuje przy ucisku na korzeń S1. Z tego powodu najczęściej dolegliwość ta mylona jest z zapaleniem nerwu kulszowego. Podrażnione więzadło krzyżowo-guzowe może być źródłem bólu całej kończyny dolnej wraz z palcami. Promieniuje on wzdłuż kończyny dolnej na tylnej stronie uda i podudzia, dochodząc do pięty, podeszwowej części stopy, a nawet do trzeciego i czwartego palca. Odruchowe napięcie mięśni tylnej części kończyny dolnej wywoływać może objawy pseudoneurologiczne (drętwienie i mrowienie), a także pseudonaczyniowe (uczucie zimnej stopy). Pacjenci uskarżają się na te dolegliwości podczas stania, chodzenia, zakładania nogi na nogę i w czasie długotrwałego siedzenia. Ból najczęściej zlokalizowany jest w obrębie kości ogonowej, uda, podudzia albo pośladka. Może mieć charakter ostry lub podostry, a z czasem przejść w stan chroniczny trwający dziesiątki lat [12].

Więzadło krzyżowo-guzowe jest jednym z trzech więzadeł pośrednio wzmacniających staw krzyżowo-biodrowy. Zbudowane jest z trzech pasm, biegnie wachlarzowato od bocznej powierzchni kości krzyżowej i częściowo guzicznej aż do guza kulszowego. Dysfunkcja tej struktury wynika z zablokowania stawu krzyżowo-biodrowego, dyskopatii lędźwiowej, a także z zespołów bólowych mięśni miednicy. W hiperlordozie lędźwiowej dochodzi do rozciągnięcia więzadła, zaś w dyslordozie do przykurczu wskutek zbliżenia się jego przyczepów [13].

Kolejnym przykładem błędnego diagnozowania są bóle wywoływane przez więzadło biodrowo-lędźwiowe. Podobnie jak więzadło krzyżowo-guzowe pośrednio wzmacnia ono staw krzyżowo-biodrowy. Często do jego podrażnienia dochodzi w wyniku zablokowania stawu, zwiększenia wygięcia lordotycznego, a także zwiększenia kąta nutacji. Ból zlokalizowany jest najczęściej w okolicy lędźwiowo-krzyżowej po stronie podrażnionego więzadła, nie promieniuje do kończyny dolnej (ewentualnie do podbrzusza). W przypadku podrażnienia więzadła występuje bolesność czwartego i piątego kręgu lędźwiowego oraz grzebienia kości biodrowej po tej samej stronie [13]. U pacjentów z bólem punktowym w obrębie pośladka warto przetestować więzadło krzyżowo-kolcowe, gdyż może być ono jego źródłem. Należałoby w trakcie diagnozowania pacjenta sprawdzić napięcie i tkliwość więzadeł, a także skontrolować ruchomość stawu za pomocą testu Piedallu, wyprzedzania, kompresji i testu rozciągowego oraz objawu Derbolowsky'ego.

Do dysfunkcji stawu krzyżowo-biodrowego mogą przyczyniać się także czynniki zewnętrzne (mechaniczne), takie jak: urazy związane z upadkiem, wypadki komunikacyjne, przeciążenia, a także podnoszenie ciężarów w nieprawidłowej pozycji, w której dochodzi do wyłączenia mięśni stabilizacyjnych miednicy [14].

Częstość występowania dysfunkcji stawu krzyżowo-biodrowego jest również zależna od wieku. Osoby kończące 45. r.ż. stają się bardziej narażone na dysfunkcję stawu. Także u pracowników biurowych spędzających większość czasu w pozycji siedzącej oraz u osób z ograniczoną aktywnością fizyczną ryzyko zablokowania stawu krzyżowo-biodrowego jest większe. Zależności takiej nie zauważono w odniesieniu do płci [15].

Według Sembrano i Polly oraz innych autorów dolegliwości bólowe odcinka lędźwiowo-krzyżowego w 5\% spowodowane są zablokowaniem stawu krzyżowo-biodrowego $[16,17,18,19,20]$.

\section{WNIOSKI}

Stawy krzyżowo-biodrowe ustalają prawidłowe ustawienie kości krzyżowej względem miednicy i odcinka lędźwiowego kręgosłupa oraz zapewniają prawidłową amortyzację i przenoszenie obciążeń z miednicy na kręgosłup [21]. 
Zagrożenie zablokowaniem stawu wzrasta wraz z wiekiem, zmniejszeniem aktywności ruchowej oraz siedzącym charakterem pracy, natomiast nie zależy od płci. Długotrwałe dysfunkcje tych stawów z czasem prowadzą do powstania zaburzeń na wyższych piętrach kręgosłupa, będących źródłem stałego bólu, który najczęściej zlokalizowany jest w okolicy kręgosłupa lędźwiowego, pośladka lub kończyny dolnej.

Źródłem dolegliwości może być również podrażnienie więzadeł pośrednich i bezpośrednich tego stawu.

\section{PIŚMIENNICTWO}

1. Lisiński P, Majewska M, Samborski W. Efektywność ćwiczeń wzmacniających mięśnie u chorych z przepukliną jądra miażdżystego w dolnej części kręgosłupa lędźwiowego. Baln Pol 2006;1:36-9.

2. Poley RE, Borchers JR. Sacroiliac joint dysfunction: evaluation and treatment. Phys Sportsmed 2008;36(1):42-9. doi: 10.3810/psm. 2008.12.10.

3. Chen YC, Fredericson M, Smuck M. Sacroiliac joint pain syndrome in active patients: a look behind the pain. Phys Sportsmed 2002;30(11):30-7. doi: 10.3810/psm.2002.11.527.

4. Gnat R, Saulicz E, Kokosz M, Kuszewski M. Biomechaniczne aspekty nowoczesnych modeli stabilizacji miednicy. Cześć I: staw krzyżowo-biodrowy i mechanizm autoryglowania. Fizjoter Pol 2006;6(4):280-8.

5. Gnat R, Saulicz E, Kuszewski M. Zaburzenia funkcjonowania systemów stabilizacyjnych kompleksu biodrowo-miedniczno-lędźwiowego. Fizjoter Pol 2006;14(3):83-91.

6. Levangine PK. Four clinical tests of sacroillac joint dysfunction: the association of test results with inominate torsion among patients with and without low back pain. Phys Ther 1999;79(11):1043-57.
7. Bemis T, Daniel M. Validation of the long sitting test on subjects with iliosacral dysfunction. J Orthop Sports Phys Ther 1987;8(7):336-45.

8. Cibulka MT, Koldehoff RM. Clinical usefulness of a cluster of sacroiliac joint tests in patients with and without low back pain. J Orthop Sports Phys Ther 1999;29(2):83-92. doi: 10.2519/jospt.1999.29.2.83.

9. Lee D. Obręcz biodrowa. Warszawa: DB Publishing; 2001.

10. Freburger JK, Riddle D. Using published evidence to guide the examination of the sacroiliac joint region. Phys Ther 2001;81(5):1135-43.

11. Huijbregts P. Sacroiliac joint dysfunction: evidence-based diagnosis. Orthop Division Rev 2004;6:18-44.

12. Klein P, Sommerfeld P. Biomechanik der menschlichen Gelenke. München: Elsevier Urban \& Fischer; 2004.

13. Słobodzian J, Rakowski A. Terapia manualna w zespołach bólowych kręgosłupa lędźwiowo-krzyżowego. Poznań: Wydawnictwo Centrum Terapii Manualnej; 2001.

14. Slipman CW, Patel RK, Whyte WS. Diagnosis and managing sacroiliac pain. J Musculoskelet Med 2001;18:325-32.

15. Rzepka A, Kusza K, Jakubczyk M. Rola stawu krzyżowo-biodrowego w powstawaniu zespołu bólowego dolnego odcinka kręgosłupa. Kwart Ortop 2009;4:483-8.

16. Pytel A, Wrzosek Z. Główne czynniki ryzyka dyskopatii lędźwiowo-krzyżowej kręgosłupa. Kwart Ortop 2009;3:331-8.

17. Pyskło B, Styczyński T. Znaczenie prognostyczne zespołu rzekomokorzeniowego u chorych na dyskopatie lędźwiowego odcinka kręgosłupa. Reumatologia 1998;6(3):269-74.

18. Sipko T, Janicki K, Barczyk K, Demczuk-Włodarczyk E. Objawy rzekomokorzeniowe u pacjentów z chorobą dyskową kręgosłupa lędźwiowego. Ortop Traumatol Rehabil 2006;8(6):663-71.

19. Piecuch R, Targońska-Stępniak B, Majdan M. Aktualne poglądy w leczeniu choroby zwyrodnieniowej stawów. Lekarz 2008;(6):81-8.

20. Sembrano JN, Polly DW. How often is low back pain not coming from the back? Spine 2009;34(1):27-32.

21. Hak A, Krawczyńska J, Kamińska E, Czerwiak G, Zapart S, Janiszewski M, et al. Wpływ statyki miednicy na postawę ciała w aspekcie terapii manualnej. Med Manual 2005;9(1-2):52-5. 